\title{
KONTRIBUSI PERAN PEREMPUAN PESISIR TERHADAP KEBUTUHAN EKONOMI KELUARGA DI KAMPUNG PETTA KABUPATEN KEPULAUAN SANGIHE
}

\author{
The Role of Coastal Women's Contribution To Family Economic Needs \\ In Petta Village Sangihe Island Regency
}

\author{
Costantein Imanuel Sarapil ${ }^{1)}$, Eunike Irene Kumaseh ${ }^{1)}$, Ganjar Ndaru Ikhtiagung'), \\ Erlin Puspaputri ${ }^{3)}$ \\ ${ }^{1}$ Program Studi Teknologi Penangkapan Ikan, Politeknik Negeri Nusa Utara \\ Jl. Kesehatan No. 1 Kelurahan Sawang Bendar, Tahuna, 95812 \\ ${ }^{2}$ Politeknik Negeri Cilacap Jl. Dr. Sutomo No. 1 Sidakaya, Cilacap 537992, Indonesia \\ ${ }^{3}$ Direktorat Kelembagaan, Ditjen Dikti, Kementerian Pendidikan dan Kebudayaan, \\ Gedung Dikti, Pintu Satu Senayan, Jl. Jenderal Sudirman, Jakarta 10270 \\ Email: sarapilcostantein79@gmail.com
}

\begin{abstract}
Abstrak: Penelitian ini bertujuan untuk mengetahui kontribusi peran perempuan pesisir dalam memenuhi kebutuhan ekonomi keluarga dan berapa besar presentase kontribusi perempuan dalam menopang ekonomi keluarga di Kampung Petta Kecamatan Tabukan Utara Kabupaten Kepulauan Sangihe. Pengambilan data dilakukan dengan cara observasi atau pengamatan yaitu kegiatan keseharian manusia dengan menggunakan pancaindra. Karena itu, obervasi adalah kemampuan seseorang untuk menggunakan pengamatannya melalui hasil kerja pancaindera mata serta dibantu dengan pancaindra lainnya untuk menghimpun data penelitian. Rata - rata keuntungan perempuan pesisir Rp 160.000 / hari, rata - rata pendapatan Rp 2.750.000, serta besar kontribusi perempuan pesisir terhadap kebutuhan ekonomi keluarga yaitu sebesar 46,5\%. Hal ini menunjukkan bahwa Perempuan pesisir mempunyai peran yang penting dalam memenuhi kebutuhan keluarga di Kampung Petta. Perlu adanya kebijakan Pemerintah yang memberikan peluang bagi para perempuan pesisir untuk mengembangkan usaha mereka dan berkontribusi secara aktif bagi masyarakat.
\end{abstract}

Kata kunci: kontribusi peran posisi perempuan; perempuan pesisir; kebutuhan ekonomi; keluarga nelayan.

\begin{abstract}
Abtract: This study aims to determine the contribution of the role of coastal women in fulfilling the economic needs of the family and how much is the percentage in contribution of women in supporting the family economy in Petta Village, Tabukan Utara District, Sangihe Islands Regency. Data collection was carried out by observation, namely human daily activities using the eye senses as their main aid in addition to other senses such as ears, smell, mouth, and skin. Therefore, observation is a person's ability to use his observations through the work of his senses and is assisted by other senses to collect research data. The average profit for coastal women is Rp. 160,000 / day, the average income is Rp. 2,750,000, and the contribution of coastal women to the economic needs of the family is 46,5\%. This shows that coastal women have an important role in fulfill the needs of families in Petta Village. There needs a government policy that provides opportunities for coastal women to develop their businesses and contribute actively to society.
\end{abstract}

Keyword: contribution of the role of coastal women; coastal women; economy needs; fisher family

\section{PENDAHULUAN}

Sumber daya perikanan merupakan aset alam yang diekstraksi untuk memberikan manfaat sebesarbesarnya bagi manusia, namun demikian aspek manfaat ini memiliki berbagai dimensi, ekonomi, ekologi maupun sosial (Fauzi, 2010). Peranan domestik perempuan adalah peranan sosial dalam rumah tangga, seperti memasak, mengurus anak, dan melayani suami; 
sedangkan peranan publik adalah peranan sosial yang berkaitan dengan aktivitas sosial, ekonomi, dan politik di luar rumah tangga (Kusnadi, 2006). Wanita merupakan salah satu komponen penting dalam pembangunan ekonomi di wilayah pesisir (Djunaidah \& Nurmalia, 2018). Peranan utama perempuan tergambar melalui kontribusinya dalam penerimaan rumah tangga (Sopamena, 2019), serta mendukung nilai tambah hasil perikanan yang menjadi pekerjaan utama suaminya (Istiqomah, 2018).

Kabupaten Kepulauan Sangihe merupakan kabupaten yang terluar di bagian Utara Indonesia yang berada di Provinsi Sulawesi Utara dan berbatasan dengan Negara Philipina. Kabpaten ini terdapat banyak pulau-pulau kecil dan memiliki luas laut sekitar $80 \%$ dari wilayah darat, Dari letak geografis inilah terlihat bahwa potensi perikanan di Kabupaten sangat besar. Kabupaten Kepulauan Sangihe terdaftar mempunyai 15 kecamatan, 22 kelurahan dan 145 desa. Kecamatan Tabukan Utara merupakan pemekaran dari Kecamatan Tabukan, yang dimana Kecamatan Tabukan dibagi menjadi tujuh kecamatan yaitu Kecamatan Tabukan Utara, Kecamatan Tabukan Tengah, Kecamatan Tabukan Selatan, Kecamatan Selatan Tengah, Kecamatan Tabukan Selatan Tenggara, Kecamatan Marore, dan Kecamatan Nusa Tabukan. Di kecamatan ini terdapat 4 pasar yaitu, pasar Kalasuge, pasar Sawang Jauh, Pasar Naha dan Pasar Petta. Pasar Petta merupakan pasar induk atau pasar yang besar sehingga, banyak orang yang datang berbelanja dan berjualan dipasar ini. Salah satunya adalah perempuan pengolah hasil perikanan yang merupakan komponen yang tidak bisa dipisahkan dalam pembangunan ekonomi nelayan di wilayah pesisir khusunya di wilayah kecamatan Tabukan Utara.

Menurut Data BPS Kabupaten Kepulauan Sangihe (2019), Kampung Petta mempunyai luas wilayah 1,92 $\mathrm{km}^{2}$ dengan jumlah penduduk sebanyak 938 jiwa, dimana Laki - laki sebanyak 468 jiwa $(49,89 \%)$ dan Perempuan 470 jiwa $(50,11 \%)$. Banyaknya penduduk Kampung Petta berdasarkan mata pencaharian ditunjukkan dalam Tabel berikut ini.
Tabel 1. Jumlah Penduduk Kampung Petta berdasarkan Mata Pencaharian.

\begin{tabular}{|c|l|c|c|}
\hline No. & \multicolumn{1}{|c|}{ Jenis Pekerjaan } & $\begin{array}{c}\text { Jumlah } \\
\text { (orang) }\end{array}$ & $\begin{array}{c}\text { Persentase } \\
(\%)\end{array}$ \\
\hline 1 & Petani & 104 & 29,38 \\
\hline 2 & Nelayan & 190 & 53,67 \\
\hline 3 & Pengusaha/Pedagang & 49 & 13,84 \\
\hline 4 & PNS & 2 & 0,56 \\
\hline 5 & Pegawai swasta & 8 & 2,26 \\
\hline 6 & TNI/Polri & 1 & 0,28 \\
\hline & Banyaknya & 354 & 99,99 \\
\hline
\end{tabular}

*Sumber: BPS Kabupaten Kepulauan Sangihe, 2019.

Berdasarkan pada Tabel 1, dapat dilihat bahwa sebagian besar penduduk di Kampung Petta memiliki mata pencaharian sebagai nelayan, dengan persentase sebesar 53,67 persen. Sedangkan, jumlah penduduk dengan mata pencaharian yang paling sedikit adalah TNI/Polri dengan persentase sebanyak 0,28 persen.

Menurut Kusnadi (2006) perhatian terhadap kawasan pesisir tidak hanya didasari oleh pertimbangan pemikiran bahwa kawasan itu tidak hanya menyimpan potensi sumber daya alam yang cukup besar, tetapi juga potensi sumber daya masyarakat mengelola sumber daya tersebut secara berkelanjutan. Salah satu unsur potensi sosial tersebut adalah kaum perempuan pesisir, khususnya istri nelayan, kedudukan dan peranan kaum perempuan pesisir atau istri nelayan. Peran istri nelayan juga sangat berpengaruh terhadap perekonomian di Kecamatan Tabukan Utara khusunya di pasar Petta yang merupakan penjual ikan di pasar tersebut. Menurut Tebaiy, et al. (2017), keberadaan perempuan sebagai penyokong dalam kondisi ekonomi rumah tangga dimana penghasilan nelayan tidaklah menentu. Peran perempuan pesisir dalam aktivitas ekonomi nyata dalam alokasi waktu yang mereka berikan (Nurlaili \& Muhartono, 2017), dimana pemberdayaan perempuan berpengaruh terhadap peningkatan kesejahteraan (Kuncoro, 2015). Umumnya, isteri nelayan mengambil peran sebagai pemasar hasil tangkapan ikan dan pengolah, ada juga yang bekerja di luar sektor perikanan (Damsiki, 2016). 


\section{METODE PENELITIAN}

Penelitian ini akan dilaksanakan selama bulan April - September 2020 di Kampung Petta Kecamatan Tabukan Utara Kabupaten Kepulauan Sangihe Propinsi Sulawesi Utara.

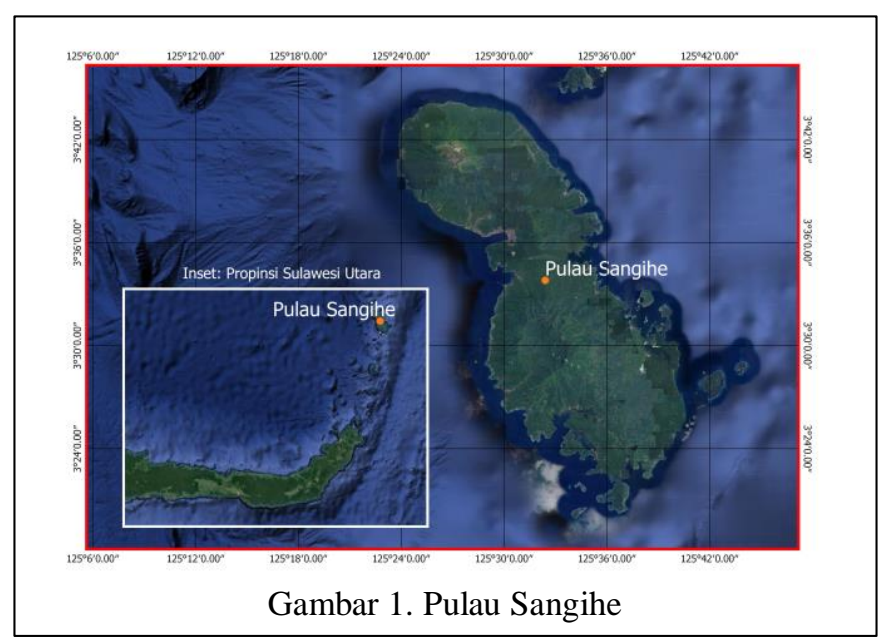

Kabupaten Kepulauan Sangihe ditunjukkan pada Gambar 1, dimana merupakan wilayah administratif dari Propinsi Sulawesi Utara. Lokasi penelitian, Kampung Petta, ditunjukkan pada Gambar 2.

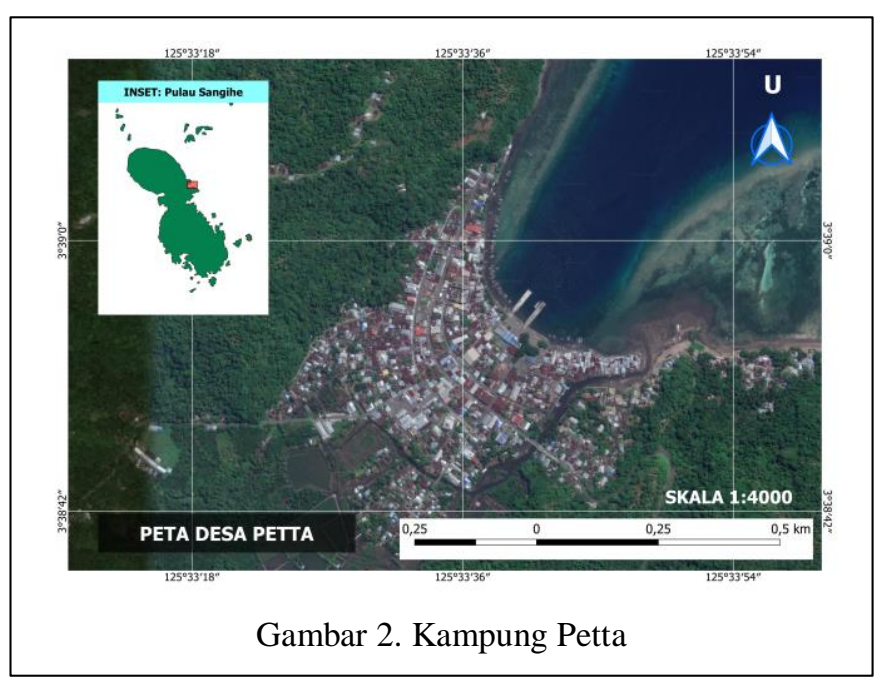

Pengambilan data dilakukan dengan cara mengumpulkan data secara langsung melalui wawancara dan observasi di tengah perempuan pesisir dalam hal ini perempuan penjual hasil perikanan sejumlah 30 responden, yang berjualan di Pasar petta kecamatan Tabukan Utara, Kabupaten Kepulauan Sangihe. Menurut Bungin (2008), wawancara mendalam secara umum adalah proses memperoleh keterangan untuk tujuan penelitian dengan cara tanya jawab sambal bertatap muka antara pewawancara dengan informan atau orang yang diwawancarai, dengan atau tanpa menggunakan pedoman (guide) wawancara, dimana pewawancara dan informan terlibat dalam kehidupan sosial yang relatif lama. Pengambilan data juga dilakukan dengan cara observasi atau pengamatan yaitu kegiatan keseharian manusia dengan menggunakan pancaindra mata sebagai alat bantu utamanya selain pancaindra lainnya seperti telinga, penciuman, mulut, dan kulit.

Analisa data secara deskriptif kualitatif disebut pula dengan kuasi kualitatif atau desain kualitatif semu. Karena itu, metode ini belum sepenuhnya kualitatif karena konstruksinya masih dipengaruhi oleh tradisi kuantitatif. Dikatakan kuasi kualitatif, juga karena sifatnya yang tidak terlalu mengutamakan makna, sebaliknya penekanannya pada deskriptif menyebabkan format deskriptif kualitatif lebih banyak menganalisis permukaan data, hanya memperhatikan proses - proses kejadian suatu fenomena, bukan kedalaman data ataupun makna data. Hal inilah juga yang banyak dilakukan dalam penelitian social dengan berbagai format penelitian kuantitatif. Walaupun demikian, deskriptif-kualitatif mengadopsi cara berpikir induktif untuk mengimbangi cara berpikir deduktif (Bungin, 2008).

Handayani \& Artini (2009) dalam Djunaidah \& Nurmalia (2016) menyatakan bahwa analisis yang digunakan untuk mengetahui kontribusi pendapatan perempuan pesisir terhadap total pendapatan keluarga menggunakan rumus sebagai berikut.

$$
\mathrm{P}=\frac{P_{w}}{P_{d}} \times 100 \%
$$

dimana,

$P \quad$ : Presentase pendapatan responden (perempuan pesisir) terhadap keluarga

$P_{w}$ : Pendapatan rumah tangga yang berasal dari perempuan pesisir

$P_{d}:$ Total pendapatan rumah tangga 


\section{HASIL DAN PEMBAHASAN}

\section{Profil Perempuan Pesisir di Kampung Petta}

Perempuan pesisir di Kampung Petta banyak merupakan pedagang ikan, baik sebagai pedagang eceran ikan maupun ada juga yang menjadi pengolah dan penjual ikan olahan. Ikan yang diambil merupakan ikan hasil tangkapan suami, ataupun hasil tangkapan yang dibeli dari para nelayan yang berasal dari pulau pulau kecil di wilayah Kecamatan Nusa Tabukan. Tempat pendaratan ikan yaitu di Pelabuhan Tua Petta dan juga di wilayah pesisir di Kampung Petta, seperti yang ditunjukkan pada Gambar 3.

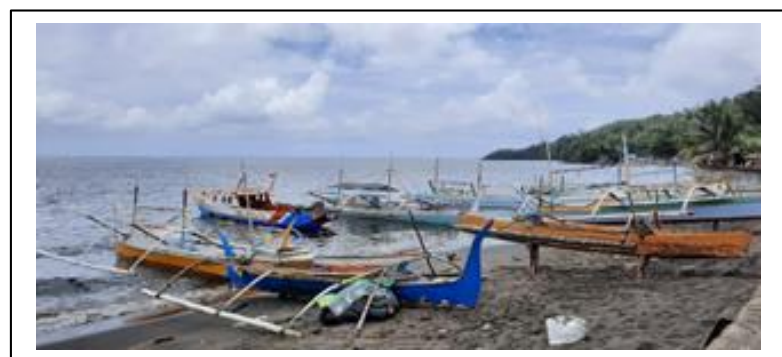

Gambar 3. Pesisir pantai Kampung Petta

1) Pedagang Eceran Ikan

Perempuan pesisir yang menjadi pedagang eceran ikan, seperti yang ditunjukkan pada Gambar 4, menjual ikan mereka di Pasar Petta. Namun, ada juga yang membawa dagangan mereka ke pasar - pasar tradisional di sekitar Kampung Petta, di wilayah Kecamatan Tabukan Utara.

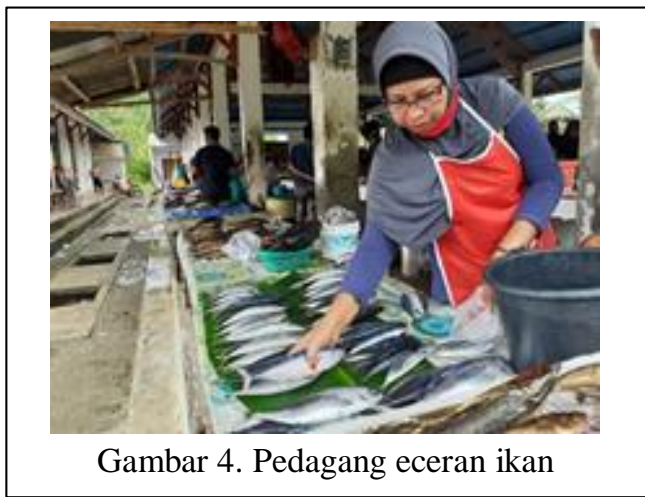

2) Pengolah dan Penjual Ikan Olahan

Beberapa orang perempuan pesisir di Kampung Petta juga merupakan Pengolah dan Penjual ikan olahan khususnya ikan asap. Tempat pengolahan ikan asap, dalam Bahasa lokal disebut Porno, seperti yang ditunjukkan pada Gambar 5. Hasil olahan ikan tersebut, selain dijual di Pasar Petta, ada juga yang dijual di pasar - pasar tradisional di sekitar Kampung Petta. Namun, ada juga ikan olahan dijual ke Pasar Tradisional Towo'e Tahuna, ibukota Kabupaten Kepulauan Sangihe.

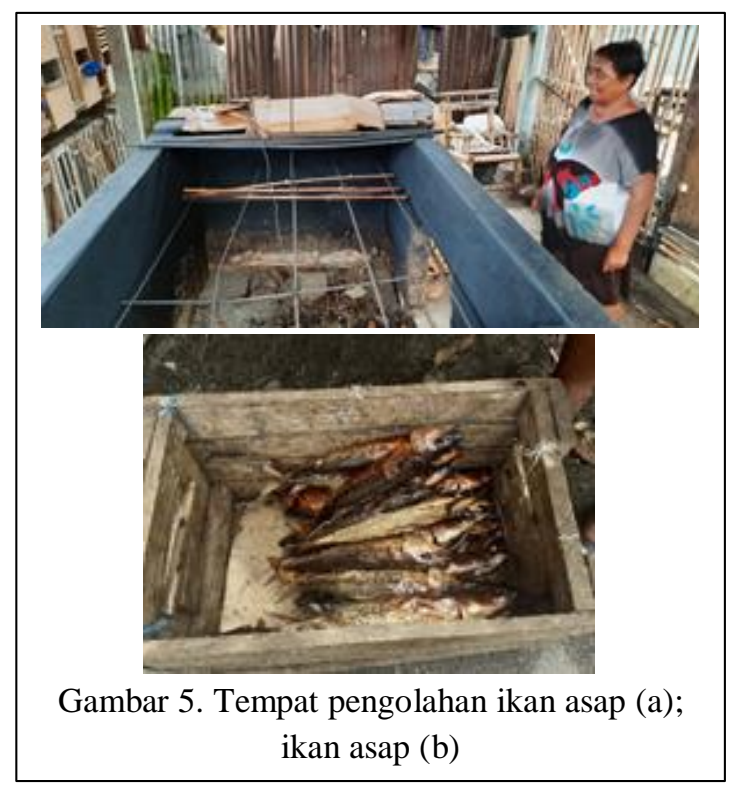

\section{Kontribusi Peran Perempuan Pesisir}

Menurut Sarapil \& Wuaten (2017), Pola hidup ialah sistem nilai serta sikap dalam keluarga dan lingkungan. Adanya peran perempuan pesisir merupakan satu tatanan pola dalam keluarga nelayan di Kampung Petta, bahkan secara umum. Menurut Sarapil, et al. (2019), perempuan pesisir berperan dalam meningkatkan pendapatan keluarga.

Rata - rata keuntungan pendapatan setelah menjual ikan yaitu sebesar Rp 160.000 /hari, rata - rata pendapatan Rp 2.750.000 per bulan. Menurut Azizi et al. (2012), pendapatan lebih dari Rp 1.000.000/ bulan, merupakan pendapatan tinggi. Sehingga, pendapatan nelayan bersama dengan isteri di Kampung Petta merupakan pendapatan yang tergolong tinggi. Serta, besar kontribusi perempuan pesisir terhadap kebutuhan ekonomi keluarga yaitu sebesar $93 \%: 2=46,5 \%$, karena pada saat penjualan ikan, suami mereka membantu mengangkat dan menjual ikan. Artinya, pendapatan yang ada merupakan hasil usaha suami dan 
isteri nelayan. Hal ini menunjukkan bahwa para perempuan pesisir juga mengambil bagian dalam menopang penghidupan keluarga nelayan. Hal ini juga berpengaruh terhadap pengambilan keputusan dalam keluarga. Para perempuan pesisir menjadi salah satu tiang penopang keluarga dalam memenuhi kebutuhan hidup sehari - hari. Ada juga yang ditopang dengan usaha warung kecil - kecilan, tetapi pendapatan terbesar dalam keluarga berasal dari hasil penjualan ikan, baik ikan mentah maupun olahan. Para suami membantu usaha mereka dalam berjualan.

Menurut Istiqomah (2018), peran kontribusi perempuan dalam memenuhi kebutuhan ekonomi keluarga yaitu sebesar 45 - $100 \%$, dimana kaum perempuan mampu meningkatkan pendapatan keluarga. Dalam keluarga nelayan yang tergolong rendah\lemah kondisi ekonominya, peran perempuan sebagai pencari nafkah kurang diperhitungkan sebagai kelompok kerja yang produktif (Parwadi, 2005), peran isteri yang produktif hanya dianggap membantu suami dalam memenuhi kebutuhan hidup (Hikmah, et al., 2009), padahal perempuan pesisir berperan aktif dalam menunjang ekonomi keluarga (Nugraheni S., 2012). Menurut Azizi, et al. (2012), Pemerintah dapat menunjang dengan adanya program yang memperhatikan dan menyedikan peluang bagi para perempuan pesisir untuk mengembangkan diri, seperti mempermudah akses permodalan usaha di bidang perikanan, serta pendampingan dari Pemerintah Daerah maupun BUMD/BUMN.

\section{KESIMPULAN}

Berdasarkan hasil yang diperoleh, maka dapat disimpulkan bahwa rata - rata keuntungan perempuan pesisir Rp 160.000 / hari, rata - rata pendapatan Rp 2.750.000, serta besar kontribusi perempuan pesisir terhadap kebutuhan ekonomi keluarga yaitu sebesar 46,5\%. Hal ini menunjukkan bahwa Perempuan pesisir mempunyai peran yang penting dalam memenuhi kebutuhan keluarga di Kampung Petta. Perlu adanya kebijakan Pemerintah yang memberikan peluang bagi para perempuan pesisir untuk mengembangkan usaha mereka dan berkontribusi secara aktif bagi masyarakat.

\section{DAFTAR RUJUKAN}

Azizi, A., Hikmah, \& Pranowo, S. A. 2012. Peran Gender dalam Pengambilan Keputusan Rumah Tangga Nelayan di Kota Semarang Utara, Provinsi Jawa Tengah. Jurnal Sosek KP, 7(1): $113-125$

Badan Pusat Statistik Kabupaten Kepulauan Sangihe. 2019. Kecamatan Tabukan Utara dalam Angka 2019. BPS Kabupaten Kepulauan Sangihe: Tahuna

Bungin, H. M. 2008. Penelitian Kualitatif: Komunikasi, Ekonomi, Kebijakan Publik, dan Ilmu Sosial Lainnya. Kencana: Jakarta

Damsiki, N. A. 2016. Peranan Perempuan dalam Peningkatan Pendapatan Rumah Tangga Nelayan di Desa Maitara. Jurnal Ilmiah Wawasan Pendidikan, Vol. 4 (3), Hal. 104 - 111 Djunaidah, I. S. \& Nurmalia, N. 2018. Peran Produktif Wanita Pesisir dalam Menunjang Usaha Perikanan di Kecamatan Tempuran, Kabupaten Karawang. Jurnal Sosek KP Vol. 13 (2), Hal 229 $-237$

Fauzi Akhmad 2010 “Ekonomi Perikanan” penerbit PT Gramedia Pustaka Utama Jakarta

Hikmah, Yulisti, M. \& Nasution, Z. 2009. Pola Pembagian Kerja dan Kontribusi Gender Terhadap Pendapatan Keluarga: Studi Kasus Rumah Tangga Nelayan di Desa Batanjung Kabupaten Kapuas. Jurnal Bijak dan Riset Sosek KP, 4(1): $93-103$

Istiqomah, T. 2018. Analisis Gender Peran Wanita Sebagai Stimulator Ekonomi Keluarga Nelayan di Pesisir Kabupaten Sidoarjo. Fish Scientiae, Vol. 8 (1), Hal 25 - 37

Kuncoro, A. 2015. Pemberdayaan Perempuan Pesisir Pengaruhnya bagi Peningkatan Kesejahteraan Masyarakat (Studi pada Desa Nelayan Sambiroto 
Kecamatan Tayu Kabupaten Pati). Jurnal Buletin

Ekonomi, Vol. 13 (1), Hal 87 - 96

Kusnadi. 2006. Perempuan Pesisir. LKis Pelangi Aksara: Yogyakarta

Kusnadi. 2006. Nelayan : Strategi Adaptasi dan Jaringan

Sosial. Bandung Humaniora Utama Press: Bandung

Nirwati. 2018. Kontribusi Perempuan Pesisir Terhadap

Peningkatan Pendapatan Rumah Tangga

Nelayan (Studi Kasus Kecamatan Galesong

Kabupaten Takalar). Skripsi. Program Studi

Sosial Ekonomi Perikanan Departemen

Perikanan Fakultas Ilmu Kelautan dan Perikanan

Universitas Hasanuddin Makassar

Nugraheni S., W. 2012. Peran dan Potensi Wanita dalam

Pemenuhan Kebutuhan Ekonomi Keluarga

Nelayan. Journal of Eduactional Social Studies,

1(2): $104-111$

Nurlaili \& Muhartono, R. 2017. Peran Perempuan Nelayan dalam Usaha Perikanan Tangkap dan Peningkatan Ekonomi Rumah Tangga Pesisir Teluk Jakarta. Jurnal Sosek KP, Vol. 12 (2), Hal. $203-212$

Parwadi, R. 2005. Peranan Istri dalam Pemenuhan Kebutuhan Rumah Tangga Nelayan di Kalimantan Barat. Jurnal Populasi, 16(2): 171 194

Pasaribu, A. T. M. 2018. Peranan Perempuan Pesisir dalam Meningkatkan Daya Tahan Ekonomi Keluarga Nelayan (Studi Kasus di Kelurahan Tanjung Leidong Kecamatan Labuhanbatu Utara Kabupaten Kualuh Leidong). Skripsi.
Departemen Kesejahteraan Sosial Fakultas Ilmu Sosial dan Ilmu Politik Universitas Sumatera Utara: Medan (http://repositori.usu.ac.id)

Sarapil, C. I., Mozes, G. N., Kumaseh, E. I., Ikhtiagung, G. N., \& Dalonto, M. S. 2020. Potret Masyarakat Nelayan Pesisir di Pulau Kalama Kecamatan Tatoareng Kabupaten Kepulauan Sangihe. AKULTURASI: Jurnal Ilmiah Agrobisnis Perikanan, 8(2): 147 - 155

Sarapil, C. I., Tamarol, J., \& Kumaseh, E. I. 2019. Potret Masyarakat Nelayan Penangkap Ikan di Pulau Lipang Kecamatan Kendahe Kabupaten Kepulauan Sangihe Propinsi Sulawesi Utara. Jurnal Ilmiah Tindalung, 5(2): $61-70$

Sarapil, C. I. \& Wuaten, J. F. Manajemen Rumah Tangga Nelayan Penangkap Ikan Tuna (Thunnus albacores) Studi Kasus di Pesisir Pantai Akembuala Kelurahan Santiago Kecamatan Tahuna Kabupaten Kepulauan Sangihe. Jurnal Ilmiah Tindalung, 3(1): $23-30$

Satria, A. 2015. Pengantar Sosiologi Masyarakat Pesisir. Yayasan Pustaka Obor Indonesia: Jakarta Sopamena, J. F. 2019. Kontribusi Perempuan Terhadap Penerimaan Rumah Tangga Masyarakat Pulau Kecil (Studi Kasus Kecamatan Teluk Ambon Kota Manado). Jurnal Ekonomi Pertanian dan Agribisnis (JEPA), Vol. 3 (4), Hal. 720 - 729

Tebaiy, S., Leiwakabessy, J., \& Wambrauw, E. T. 2017. Kontribusi Pendapatan Kelompok Usaha Perempuan Pesisir dalam Pengolahan Hasil Perikanan di Manokwari. Jurnal Sumberdaya Akuatik Indopasifik, Vol. 1 (2), Hal. 153 - 164 